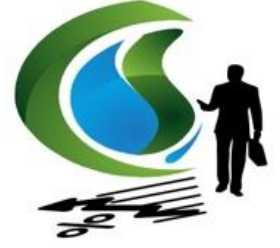

ACADEMIC JOURNAL OF ACCOUNTING AND ECONOMIC RESEARCHES
Academic Journal of Accounting and Economic Researches

ISSN: 2333-0783 (Online)

ISSN: 2375-7493 (Print)

ajaer.worldofresearches.com

\title{
A study on the Relationship between Fraud in Financial Reporting and Liquidity in Firms
}

\author{
Elham Azin ${ }^{1 *}$, Zekvan Imani ${ }^{2}$, Ali Homayoon ${ }^{3}$ \\ ${ }^{1}$ Master of Accounting, Bandar Abbas Branch, Islamic Azad University, Bandar Abbas, Iran \\ ${ }^{2,3}$ Faculty member, Department of Accounting, Bandar Abbas Branch, Islamic Azad University, Bandar Abbas, Iran
}

\begin{abstract}
A B S T R A C T
The main objective of this study is to investigate the relationship between fraud in the financial reporting and liquidity of firms listed on the Stock Exchange in Tehran. For this purpose, a sample, consisting of 85 firms listed in Tehran Stock Exchange in the 5-year period from 2010 to 2014, has been studied. To verify the hypotheses, multiple regression analysis is used. The results of the hypotheses testing indicate that there is no significant relationship between fraudulent financial reporting and liquidity (including the volume and value of transactions) in the surveyed firms. However, there is a significant negative correlation between fraud in financial reporting and liquidity (including stock turnover and the number of trading days) in the surveyed firms.
\end{abstract}

Keywords: Fraud, Liquidity, Volume of Transactions, Value of Transactions, Stock Turnover

\section{INTRODUCTION}

In recent years, fraud in financial reporting and accounting has grown considerably. Therefore, the issue of fraudulent financial reporting and accounting has been the subject of particular attention, recently. Falsification of financial statements involves the manipulation of their constituent elements through overstating assets, liabilities selling and profits or understating the liabilities, expenses and loss. When the financial statements contain a significant distortion so that the components of the financial statement do not indicate the reality, it is said that fraud has taken place' ${ }^{\mathbf{1}}$. Fraud is the conscious manipulation of financial statements by management that leads to misleading of investors and creditors ${ }^{2}$.

Fraud is referred to intentional acts of one or more directors, employees or third parties that lead to the presentation of false financial statements. Fraud in the financial statements is any deliberate act by the firm to mislead the users of these financial statements, especially investors and creditors through the preparation and issuance of financial statements that contain significant mistakes. Fraud may include the following cases:

\footnotetext{
* Corresponding Author: elhamazin00@gmail.com

To cite this article: Azin, E., Imani, Z., Homayoom, A. (2016). A study on the Relationship between Fraud in Financial Reporting and Liquidity in Firms. Academic Journal of Accounting and Economic Researches, 5 (2), 2232.
} 


\section{A study on the Relationship between Fraud in Financial Reporting and Liquidity in Firms}

1. Manipulation, falsification or alteration of accounting records and documents or other documents in order to obtain unlawful and illegal financial benefits, misuse assets, or steal them.

2. Misrepresentation of the financial effects of transactions or removal of them from the records and documents.

3. Transactions recorded without supporting documentation (external transactions).

4. Misuse of accounting practices

Fraud in firms, increases the ambiguity and complexity for external users. This means that the individuals lose their trust in "fraudulent" firm and the other aspects of the firm's operations and reporting will be questioned ${ }^{3}$. In fact, fraudulent financial reporting leads to provide false information to the market and affects the market efficiency in the allocation of resources that results in the investor's confidence lapse in the market.

One of the most important factors considered by many investors in capital markets is the liquidity of the shares. Liquidity is one of the main functions of the stock exchange. Investors are always asking for stocks that can be traded with the lowest possible cost ${ }^{4}$.

Liquidity can be investigated both at the level of individual securities, such as a fixed share, and at the level of the whole stock market. Liquidity is defined as the ability to buy or sell the desired amount of securities at market prices and in a short period of time. This feature is valuable, so that in the same conditions, securities with higher liquidity, in comparison with securities with lower liquidity, will have higher prices. From the perspective of price impact, liquidity is defined as the market's ability to absorb the huge volume of trades without causing severe fluctuations in the price. In addition, the main feature of liquidated markets is the low distance between bids and asks prices. Similarly, lack of liquidity represents the effect that order procedure will have on the price.

Liquidity can be defined as the probability of handling a transaction with the price equal to the previous transaction price. Liquidity is an important market criterion. In such a market prices move slowly and the gap between bid and ask prices is close to zero. Stock liquidity of any firms and the capital market is important from various aspects that among them we can mention the importance of liquidity in market growth and development and as the main index of market development, the impact on capital costs, the factor of performance improvement of firm and the overall economy, the success guarantee of public offerings of new shares, the significant factor in portfolio management with risk and return, the impact on the effectiveness of risk cover instruments, the central role of market liquidity in the price formation, the success factor of new stock public offerings and reducing costs and risks of subscriptions and market makers and stability of financial systems $\mathbf{5}$.

Given the key role of committing fraud in the loss of credibility and increased uncertainty and reduced liquidity of the firm, as well as the importance of liquidity in the price discovery process and in the distribution of more financial risk by reducing the cost of portfolio, and for motivating the investors in the transaction decisions, this study aims to investigate the effect and correlation between fraud in the financial reporting and liquidity of firms. Therefore, regard to the main objective, this research is to answer the question, that whether there is a significant relationship between fraudulent financial reporting and liquidity in listed firms in Tehran Stock Exchange. 


\section{LITERATURE REVIEW}

Liquidity can be investigated both at the level of individual securities, such as a fixed share, and at the level of the whole stock market. Liquidity is defined as the ability to buy or sell the desired amount of securities at market prices and in a short period of time. This feature is valuable, so that in the same conditions, securities with higher liquidity, in comparison with securities with lower liquidity, will have higher prices ${ }^{6}$.

From the perspective of price impact, liquidity is defined as the market's ability to absorb the huge volume of trades without causing severe fluctuations in the price. In addition, the main feature of liquidated markets is the low distance between bids and asks prices. Similarly, lack of liquidity represents the effect that order procedure will have on the price ${ }^{7}$.

Liquidity can be defined as the probability of handling a transaction with the price equal to the previous transaction price. Liquidity is an important market criterion. In such a market prices move slowly and the gap between bid and ask prices is close to zero.

According to Black, liquidated market is a market that has high strength, depth and flexibility and typically shows the real and fair prices of assets. Strength of the market is the spot prices of buying and selling of a contract or the difference between bids and asks prices. Depth of the market in the derivatives market is the number of required contracts for changing in the price and represents the impact of high volume transactions on prices. In simple words, the depth of the market indicates the volume of market orders. To determine the depth of the market, two important dimensions, including the rate of price change and the size of price changes would be taken into consideration. Flexibility of the market refers to the time required to return prices to equilibrium after the occurrence of accidental shocks. Flexibility is the period that should be taken after sharp price fluctuations that the market will return to its equilibrium.

Rahmani et al (2010) examined the relationship between institutional ownership and stock liquidity in Iran. In this study, in order to separate the effects of various functions of institutional owners on stock liquidity, two criteria of institutional ownership amount and institutional ownership concentration have been used. Fifteen different transactional and informational criteria were defined for liquidity. 138 firms during the period 2005 to 2009 were selected using elimination sampling and the research hypotheses were tested using multiple linear regression. The results show that there is a significant positive relationship between institutional ownership amount and stock liquidity and institutional ownership concentration reduces firms' stock liquidity. These ties have been observed in both transactional measures such as volume of transactions, the percentage of free float and Amihoud criterion, and informational measures such as price gaps in stock demand and supply ${ }^{\mathbf{8}}$.

Kazemi and Haider (2012) investigated the relationship between stock liquidity and investment opportunities. In this paper, the relationship between stock liquidity, which is measured by the criterion of the gap between the buying price and the selling price of shares, and investment opportunities in the Tehran Stock Exchange during the years 2003 to 2010 has been evaluated. Results show that there is a significant positive relationship between stock liquidity and investment opportunities. In addition, the results indicate that there is a significant negative correlation between stock liquidity and shareholders expected return. In other words, stock liquidity is one of the factors that increases investment opportunities and decreases the cost of equity capital ${ }^{9}$. 


\section{A study on the Relationship between Fraud in Financial Reporting and Liquidity in Firms}

Chen et al (2013) in an article entitled corporate fraud, external liability and cash policies, found that the cost of corporate liability is significantly associated with corporate fraud. Due to the expensive external finance in companies with fraudulent reporting, more cash is kept to deal with negative shocks. In addition, due to the precautionary motive, an increase in cash will be observed after the corporates' fraud. Furthermore, fraud in corporates will lead to financial constraints. After the fraud in corporates, positive cash flow sensitivity to cash flow increases ${ }^{\mathbf{1 0}}$.

Sadr et al (2014) examined the relationship between firms' life cycle and stock liquidity of the firms. To test the research hypotheses, comparison test of Central Index of more than two independent populations has been used. The results of 459 firm-year during the period 2009 to 2011 show that the firm's stock liquidity in the maturity period is higher than the period of decline, and in periods of growth and maturation are equal ${ }^{11}$.

Kuvvet (2015) on a study entitled "The relationship between corporate fraud and liquidity" examined the relationship between fraud and liquidity using a sample of 202 firms listed in the Stock Exchange of America between 1993 and 2005. The results indicate that there is a significant negative correlation between fraud and liquidity. In addition, the results show that the complexity and severity of fraudulent activities not only reduce the liquidity, but also the presence of fraud is very important for investors and liquidity has higher negative impact on the fraudulent firms with poor corporate governance, in comparison with firms with strong corporate governance ${ }^{\mathbf{1 2}}$.

\section{RESEARCH HYPOTHESES}

With respect to the issues mentioned in the introduction for clarification of research topic, and with regard to theoretical principles and literature, the following hypotheses are presented to collect information on their basis and then proceed to accept or reject the hypotheses.

Research Main Hypothesis: There is a significant relationship between fraud in financial reporting and liquidity in the firms.

The first sub-hypothesis: There is a significant relationship between fraud in financial reporting and volume of transactions in the firms.

The second sub-hypothesis: There is a significant relationship between fraud in financial reporting and value of transactions in the firms.

The third sub-hypothesis: There is a significant relationship between fraud in financial reporting and stock turnover in the firms.

The fourth sub-hypothesis: There is a significant relationship between fraud in financial reporting and the number of transactions days in the firms.

\section{METHODOLOGY}

Methodology of the present study is correlational in terms of nature and content. Using secondary data extracted from the financial statements of listed firms on Tehran Stock Exchange, the correlation relationship is analyzed. This study is conducted within the framework of deductive - inductive reasoning. Correlation methodology is applied to discover the correlation between variables. Correlation research is one type of descriptive research. In the present study we first examine the correlation between the research variables and in the case of presence of correlation between variables, multiple regression models will be estimated. Furthermore, the study is post - event (quasi-experimental). This means that it is performed on the basis of past and historical information (firms' financial statements) analysis. The present 
research is also among library and causal -analytical studies, and based on analysis of panel data (panel data).

\section{Statistical Population and Sample and Study Period}

The population consists of all firms listed on the Tehran Stock Exchange. The sample includes 85 firms for the five-year period from 2010 to 2014. The sample is selected using systematic elimination based on the following criteria:

1. The firms' fiscal year end is March 19.

2. The firms are not among financial firms (such as banks, insurance institutes) and investment firms.

3. The firms have no change in their fiscal year during the study period.

\section{Data Collection and Processing}

Since the present research methodology is field study and deals with firms' real data, data is collected from various sources, including CDs of Tehran Stock Exchange, Tadbir Pardaz Application, and information site of the Stock Exchange and stock organization. SPSS software and Excel software are used to process information.

$$
\begin{aligned}
& \text { Research Model and Variables } \\
& T V_{i, t}=\beta_{0}+\beta_{1} \text { Fraud }_{i, t}+\beta_{2} \text { Lev }_{i, t}+\beta_{3} \text { Size }_{i, t}+\beta_{4} R O A_{i, t}+\varepsilon_{i, t} \\
& V T_{i, t}=\beta_{0}+\beta_{1} \text { Fraud }_{i, t}+\beta_{2} \text { Lev }_{i, t}+\beta_{3} \text { Size }_{i, t}+\beta_{4} R O A_{i, t}+\varepsilon_{i, t} \\
& T S_{i, t}=\beta_{0}+\beta_{1} \text { Fraud }_{i, t}+\beta_{2} \text { Lev }_{i, t}+\beta_{3} \text { Size }_{i, t}+\beta_{4} R O A_{i, t}+\varepsilon_{i, t} \\
& N D T_{i, t}=\beta_{0}+\beta_{1} \text { Fraud }_{i, t}+\beta_{2} \text { Lev }_{i, t}+\beta_{3} \text { Size }_{i, t}+\beta_{4} R O A_{i, t}+\varepsilon_{i, t}
\end{aligned}
$$

\section{Dependent Variable:}

\section{Operational Definition of Variables}

Stock Liquidity:In this study, to measure the stock liquidity, the following variables are used:

Volume of Transactions: It is the number of traded stocks in a time slot. A firm's volume of transactions is obtained in annual intervals from databases ${ }^{\mathbf{8}}$.

Value of Transactions: It is the product of the number of traded stocks in the stock price ${ }^{8}$.

Stock Turnover: According to the viewpoint of Banerjee et al (2007), a firm's volume of stock trading turnover is considered as a proportion of traded stock to total issued stock in the desired year.

Number of Trading Days: It refers to the number of days in a specified period, in which share exchange has occurred. This measure is calculated on an annual basis.

\section{Independent Variable:}

\section{Fraud in Financial Reporting:}

Spatis $^{1}$ states that when the financial statements contain a significant distortion, so that the components of the financial statement do not indicate the reality, it is said fraud has taken place. In this study to measure fraudulent financial reporting Jones model is used for discretionary accruals and earnings management, that are as follows:

In the financial reporting process of the enterprise, managers can apply earnings management by the manipulation of discretionary accruals. The starting point to measure discretionary accruals is total accruals. 


\section{A study on the Relationship between Fraud in Financial Reporting and Liquidity in Firms}

The dependent variable of this study is discretionary accruals that is taken into account as an indicator for measuring fraud. Discretionary accruals are the items, on which the managers have discretion. In the present research, Dechow et al method, which is known as "Jones' Adjustment Model", is used to detect fraud. In this method, first, the total accrual is calculated as follows:

$\mathrm{TA}=\mathrm{NI}-\mathrm{CFO}$

where;

TA: total accruals

NI: net income

CFO: cash flow from operations

Then, the following model is fitted for total accruals against changes in sale and fixed assets cost of the course:

$\frac{T A_{i, t}}{A_{i, t}-1}=\propto_{1}\left(\frac{1}{A_{i, t}-1}\right)+\propto_{2}\left(\frac{\Delta R E V_{i, t}}{A_{i, t}-1}\right)+\propto_{3}\left(\frac{P P E_{i, t}}{A_{i, t}-1}\right)+\varepsilon_{i, t}$

In this regard:

Ai,t-1: Total assets of the firm in the first period

$\triangle \mathrm{REVi}, \mathrm{t}$ : Change in net income (sales) of the firm

PPEi,t: Amount of property, plant and equipment

$\alpha 1$ and $\alpha 2$ and $\alpha 3$ are the estimator parameters specific to the firm.

Non-discretionary accruals (NDA) is estimated as follows:

$$
\mathrm{NDA}_{\mathrm{i}, \mathrm{t}}=\propto_{1}\left(\frac{1}{\mathrm{~A}_{\mathrm{i}, \mathrm{t}-1}}\right)+\propto_{2}\left(\frac{\Delta \mathrm{REV}_{\mathrm{i}, \mathrm{t}}-\Delta \mathrm{REC}_{\mathrm{i}, \mathrm{t}}}{\mathrm{A}_{\mathrm{i}, \mathrm{t}-1}}\right)+\propto_{3}\left(\frac{\mathrm{PPE}_{\mathrm{i}, \mathrm{t}}}{\mathrm{A}_{\mathrm{i}, \mathrm{t}-1}}\right)+\varepsilon_{\mathrm{i}, \mathrm{t}}
$$

In this regard:

$\triangle \mathrm{RECi}, \mathrm{t}$ : Change in accounts receivable

After calculating the coefficients in the formula, it is possible to determine the amount of NDA (non-discretionary accruals). It should be noted that in this model, to standardize and tune the parameters in order to reduce volatility, the firm's total assets at the beginning of each period is used. If non-discretionary accruals (NDA) are deducted from the total accruals, discretionary accruals (DA) will be achieved. Therefore, discretionary accruals (DA), and to better express, research independent variable (fraud), is calculated using the modified Jones model, as follows:

$$
\mathrm{DA}_{\mathrm{i}, \mathrm{t}}=\frac{\mathrm{TA}_{\mathrm{i}, \mathrm{t}}}{\mathrm{A}_{\mathrm{i}, \mathrm{t}-1}}-\mathrm{NDA}_{\mathrm{i}, \mathrm{t}}
$$

\section{Control Variables:}

Financial leverage: is equal to the ratio of total debts to total assets.

Firm size: is equal to the natural logarithm of total assets.

Return on assets: It is the rate of return on assets of the firm that is obtained using the ratio of earnings before interest and taxes to total assets of the period. 


\section{RESULTS}

In order to study and analyze the initial data, descriptive statistics of the studied variables are calculated.

Table (1) Descriptive Statistics

\begin{tabular}{|c|c|c|c|c|c|}
\hline Variable & $\begin{array}{c}\text { Fraud in Financial } \\
\text { Reporting }\end{array}$ & $\begin{array}{c}\text { Volume of } \\
\text { Transactions }\end{array}$ & $\begin{array}{c}\text { Stock } \\
\text { Turnover }\end{array}$ & $\begin{array}{c}\text { Value of } \\
\text { Transactions }\end{array}$ & $\begin{array}{c}\text { Number of } \\
\text { Transactions Days }\end{array}$ \\
\hline Mean & 0.186 & 104489703.341 & 0.205 & 416425.760 & 128.664 \\
\hline Median & 0.060 & 8727418.0 & 0.064 & 24309.0 & 125.0 \\
\hline Standard Deviation & 0.683 & 334758549.809 & 0.479 & 1478903.891 & 71.116 \\
\hline Min. & -1.371 & 13575.0 & 0.0 & 36.0 & 1.0 \\
\hline Max. & 4.025 & 4096816478.0 & 4.405 & 17797173.000 & 320.0 \\
\hline
\end{tabular}

As can be seen, the descriptive results of research variables are provided in Table (1). The mean of fraud in financial reporting in firms is equal to 0.186 . In addition, the mean of liquidity components indicates that the mean of volume of transactions is 104489703.341 , the mean of stock turnover is 0.205 , the mean of value of transactions is $416,425.760$ and the mean of number of trading days is 128.664 .

\section{Research Hypotheses Testing}

In this section, in order to test the hypotheses (impact of variables), the t-statistic and its significance level are used. If the absolute value of the calculated $t$ is greater than the $t$ of the table, the null hypothesis is rejected and the coefficient is significant; otherwise the null hypothesis cannot be rejected. In addition, the significance level shows the least likelihood to confirm the null hypothesis based upon the desired coefficient being zero. This indicates that if the probability is greater than 5\%, the null hypothesis cannot be rejected and otherwise, the desired coefficient is significant.

First Hypothesis: There is a significant correlation between fraudulent financial reporting and the firms' volume of transactions.

As can be seen, at $5 \%$ error level, the significance level of the t-statistic of fraudulent financial reporting $(-0.656)$ is greater than $5 \%$ ( $\mathrm{sig}=0.512)$, hence $\mathrm{H} 0$ hypothesis is not rejected at confidence level higher than $95 \%$. This means that there is not a significant relationship between fraudulent financial reporting and the mentioned firms' volume of transactions.

Table (2) Results of the First Hypothesis Regression Model (Dependent Variable: Volume of Transactions)

\begin{tabular}{|c|c|c|c|c|c|}
\hline Variable & $\begin{array}{c}\text { Regression } \\
\text { Coefficient }\end{array}$ & $\begin{array}{c}\text { Standard } \\
\text { Error }\end{array}$ & t Statistic & $\begin{array}{c}\text { Significance } \\
\text { Level }\end{array}$ & Result \\
\hline Constant & 0.172 & 1.268 & 0.136 & 0.892 & - \\
\hline $\begin{array}{c}\text { Fraud in Financial } \\
\text { Reporting }\end{array}$ & -0.163 & 0.248 & -0.656 & 0.512 & $\begin{array}{c}\text { Lack of H0 } \\
\text { Rejection }\end{array}$ \\
\hline Firm Size & 1.126 & 0.086 & 13.127 & 0.000 & - \\
\hline Leverage & 0.184 & 0.433 & 0.424 & 0.672 & - \\
\hline Return on Assets & 0.444 & 0.759 & 0.585 & 0.559 & $\begin{array}{c}43.545 \\
(0.000)\end{array}$ \\
\hline $\begin{array}{c}\text { Determination Coefficient } \\
\text { Adjusted Determination } \\
\text { Coefficient }\end{array}$ & \multicolumn{2}{|c|}{0.293} & F Statistic & 1.5 \\
\hline
\end{tabular}




\section{A study on the Relationship between Fraud in Financial Reporting and Liquidity in Firms}

Second Hypothesis: There is a significant correlation between fraudulent financial reporting and the firms' value of transactions.

As can be seen, at 5\% error level, the significance level of the t-statistic of fraudulent financial reporting $(-0.479)$ is greater than $5 \%(\mathrm{sig}=0.632)$, hence $\mathrm{H} 0$ hypothesis is not rejected at confidence level higher than $95 \%$. This means that there is not a significant relationship between fraudulent financial reporting and the mentioned firms' value of transactions.

Table (3) Results of the Second Hypothesis Regression Model (Dependent Variable: Value of Transactions)

\begin{tabular}{|c|c|c|c|c|c|}
\hline Variable & $\begin{array}{c}\text { Regression } \\
\text { Coefficient }\end{array}$ & $\begin{array}{c}\text { Standard } \\
\text { Error }\end{array}$ & t Statistic & $\begin{array}{c}\text { Significance } \\
\text { Level }\end{array}$ & Result \\
\hline Constant & -0.090 & 0.052 & -1.753 & 0.084 & - \\
\hline $\begin{array}{c}\text { Fraud in Financial } \\
\text { Reporting }\end{array}$ & -0.005 & 0.010 & -0.479 & 0.632 & $\begin{array}{c}\text { Lack of H0 } \\
\text { Rejection }\end{array}$ \\
\hline $\begin{array}{c}\text { Firm Size } \\
\text { Leverage }\end{array}$ & 0.011 & 0.003 & 3.146 & 0.002 & - \\
\hline $\begin{array}{c}\text { Return on assets } \\
\text { Determination } \\
\text { Coefficient }\end{array}$ & -0.001 & 0.020 & 1.583 & 0.114 & - \\
\hline $\begin{array}{c}\text { Adjusted Determination } \\
\text { Coefficient }\end{array}$ & \multicolumn{2}{|c|}{0.029} & -0.032 & 0.974 & $3.111(0.015)$ \\
\hline
\end{tabular}

Third Hypothesis:There is a significant correlation between fraudulent financial reporting and the firms' stock turnover.

As can be seen, at 5\% error level, the significance level of the t-statistic of fraudulent financial reporting $(-2.444)$ is less than $5 \%$ ( $\mathrm{sig}=0.015)$, hence $\mathrm{H} 0$ hypothesis is rejected at confidence level higher than 95\%. This means that there is a negative (inverse) significant relationship between fraudulent financial reporting and stock turnover in the mentioned firms. It can be expressed that the higher (lower) the fraud in financial reporting in firms, the more the stock turnover will decrease (increase) in the firms.

Table (4) Results of the Third Hypothesis Regression Model (Dependent Variable: Stock Turnover)

\begin{tabular}{|c|c|c|c|c|c|}
\hline Variable & $\begin{array}{c}\text { Regression } \\
\text { Coefficient }\end{array}$ & $\begin{array}{c}\text { Standard } \\
\text { Error }\end{array}$ & t Statistic & $\begin{array}{c}\text { Significance } \\
\text { Level }\end{array}$ & Result \\
\hline Constant & -5.834 & 1.250 & -4.666 & 0.000 & - \\
\hline Fraud in Financial Reporting & -0.589 & 0.241 & -2.444 & 0.015 & H0 Rejection \\
\hline Firm Size & 1.135 & 0.084 & 13.463 & 0.000 & - \\
\hline Leverage & 0.015 & 0.449 & 0.034 & 0.973 & - \\
\hline Return on assets & 1.851 & 0.790 & 2.343 & 0.020 & - \\
\hline Determination Coefficient & \multicolumn{2}{|c|}{0.324} & F Statistic & $50.296(0.000)$ \\
\hline \multicolumn{2}{|c|}{0.317} & Durbin-Watson & 1.5 \\
\hline
\end{tabular}


Fourth Hypothesis: There is a significant correlation between fraudulent financial reporting and the firms' number of trading days.

As can be seen, at 5\% error level, the significance level of the t-statistic of fraudulent financial reporting $(-2.035)$ is less than $5 \%$ ( $\mathrm{sig}=0.043$ ), hence $\mathrm{H0}$ hypothesis is rejected at confidence level higher than 95\%. This means that there is a negative (inverse) significant relationship between fraudulent financial reporting and number of trading days in the mentioned firms. It can be expressed that the higher (lower) the fraud in financial reporting in firms, the more the number of trading days will decrease (increase) in the firms.

Table (5) Results of the Fourth Hypothesis Regression Model (Dependent Variable: Number of Trading Days)

\begin{tabular}{|c|c|c|c|c|c|}
\hline Variable & $\begin{array}{l}\text { Regression } \\
\text { Coefficient }\end{array}$ & $\begin{array}{l}\text { Standard } \\
\text { Error }\end{array}$ & t Statistic & $\begin{array}{l}\text { Significance } \\
\text { Level }\end{array}$ & Result \\
\hline Constant & 1.785 & 0.469 & 3.806 & 0.000 & - \\
\hline Fraud in Financial Reporting & -0.188 & 0.092 & -2.035 & 0.043 & $\begin{array}{c}\mathrm{H} 0 \\
\text { Acceptance }\end{array}$ \\
\hline Firm Size & 0.194 & 0.032 & 6.105 & 0.000 & - \\
\hline Leverage & 0.164 & 0.155 & 1.057 & 0.291 & - \\
\hline Return on assets & 0.667 & 0.271 & 2.459 & 0.014 & - \\
\hline Determination Coefficient & \multicolumn{2}{|c|}{0.102} & \multicolumn{2}{|c|}{ F Statistic } & $\begin{array}{l}11.868 \\
(0.000)\end{array}$ \\
\hline $\begin{array}{l}\text { Adjusted Determination } \\
\text { Coefficient }\end{array}$ & \multicolumn{2}{|c|}{0.093} & \multicolumn{2}{|c|}{ Durbin-Watson } & 1.528 \\
\hline
\end{tabular}




\section{A study on the Relationship between Fraud in Financial Reporting and Liquidity in Firms}

\section{CONCLUSION}

In this study, the relationship between fraudulent financial reporting and liquidity in listed firms on Tehran Stock Exchange is investigated. The first and second sub-hypotheses of research, based on "the presence of a correlation between fraudulent financial reporting and liquidity, including two benchmarks of firms' volume of transactions and firms' value of transactions", are disapproved in multivariate regression test. However, the third and fourth subhypotheses of research, based on "the presence of a relationship between fraudulent financial reporting and liquidity consisting of two criteria of firms' stock turnover and the firms' number of trading days" are disapproved in multivariate regression test. It is important to note that the results of hypotheses testing, in all four hypotheses suggest a negative relationship between fraudulent financial reporting and liquidity. This means that there is a negative correlation between fraud in financial reporting and stock liquidity of firms.

According to the testing results of the third and fourth sub-hypotheses of research, and consistent with the theoretical foundations and past research, it can be expressed that the more the likelihood of fraudulent financial reporting by managers increases, and the more the managers resort to unfair practices to keep their positions, the more the firms' stock liquidity (according to the two criteria of turnover of stocks and the number of trading days) will be reduced. Following firms' stock liquidity reduction, financial risk will increase through increasing the cost of management portfolio. Therefore, investors' motivation to make transactional decisions will be reduced and trading costs will increase. This would increase the gap between shareholders, investors and generally, users of financial information, and managers. Thus, according to the research literature, since the detection of fraud in financial reporting and explanation of the symptoms and signs, by the help of which the possibility of fraud in financial reporting can be realized, is necessary to assist market and users of information for the efficient allocation of financial resources, and regard to the key role of committing fraud in the loss of credibility and increase in uncertainty and reduction of firms' stock liquidity, as well as the importance of liquidity in price discovery process and more distribution of financial risk through decreasing the cost of portfolio management and increasing investors' motivation to make transactional decisions, the complexity and severity of fraudulent activities will lead to reduce stock liquidity and firms' weak performance and decrease in market fair allocation process.

\section{REFERENCES}

1. Spathis, C., (2002). Detecting False Financial Statements Using Published Data: Some Evidence from Greece. Managerial Auditing Journal, 17(4), 179-191.

2. Elliot, R., Willingham, J., (1980). Management Fraud: Detection and Deterrence. Petrocelli, New York. NY.

3. MacLeod, B., (2007). Reputations, Relationships, and Contract Enforcement. Journal of Economic Literature, 45(3), 595-628.

4. Saeedi, A., Dadar, O., (2009). Examination of the relationship between stock liquidity and liquidity indicator of the previous period in the Tehran Stock Exchange. Journal of Management Studies, 16, 75-97.Persian.

5. Fang, V.W., Noe, T.H., Tice, S., (2009). Stock Market Liquidity and Firm Value. Journal of Financial Economics, 94(1), 150-169.

6. Timothy, J., (2008). Volume, Liquidity and Liquidity Risk. Journal of Financial Economics (87).

7. Chordiaa, T., Roll, R., Subrahmanyam, A., (2000). Commonality in Liquidity. Journal of Financial Economics, 56(1), 3-28. 
8. Rahmani, A., Husseini, S.A., Rezapour, N., (2010). The relationship between institutional ownership and stock liquidity in Iran. Reviews of Accounting and Auditing, 17(61), 39-54.Persian.

9. Kazemi, H., Heidari, A., (2012). The relationship between stock liquidity and investment opportunities. Financial Knowledge of Securities Analysis Journal, 8, 29-39.Persian.

10. Chen, L., Frank, M.S., Zengyuan, S., (2013). Corporate Fraud, External Debt and Corporate Cash Policy. Electronic copy available at: $\underline{\text { http://ssrn.com/abstract }=2255410 .}$.

11. Sadr, S.A., Anvari, R.A.A., Wadiee, M.H., (2014). Evaluation of the relationship between firm life cycle and liquidity of firm's stock. Financial Management Strategy, 6, 1-25.Persian.

12. Kuvvet, E., (2015). Corporate Fraud and Liquidity. Electronic copy available at: http://ssrn.com/abstract=2496151. 